\title{
WhatsApp Grouping Class for Increasing Students' English Ability
}

\author{
Dewi Surani \\ Pendidikan Teknologi Informasi \\ Universitas Bina Bangsa \\ suranidewiahead@gmail.com
}

\author{
AR Chaerudin \\ Manajemen \\ Universitas Bina Bangsa
}

\begin{abstract}
This paper discusses the usage of WhatsApp grouping class for increasing students' English ability. This study uses descriptive qualitative research methods, with primary data in the form of semi structured online interviews, participatory observation, documentation and test result. Purposive sampling technique used to choose Informants with total 177 active members of the WhatsApp group from 8 classes. The results pretest and posttest show student's achievement increase. This achievement as evidence that WhatsApp group can be as tool or media for supporting English learning outside class. The interview also showed the majority of informants stated that existence of WhatsApp Group is useful to increase students' English ability including listening, writing, reading and speaking competencies with a series of drilling activities and interactions in groups, students are proven to be more active in English, improve their ability to read, listen, write and improve vocabulary.
\end{abstract}

Keywords: English ability, learning media, Information and Communication Technology, WhatsApp application

\section{INTRODUCTION}

The development of the internet and the number of internet users that is increasing every year. This is due to the ability of ICTs to process and disseminate information without the constraints of space and time, making it a major influence in the field of human life, including education. Utilization of ICT in education one of them is the use of online media in the form of WhatsApp Grouping social media in lectures. In its development, the WhatsApp application is not only used for daily communication needs, but also for sharing information and knowledge as in a lecture hall in general. This application is often used by virtual communities that are connected to each other and become members of one or even several WhatsApp Groups at the same time based on the affiliation of each WhatsApp user to their interests or interests in a particular problem or issue. WhatsApp can also create groups consisting of many people who can be used as media in the process of discussion forums and the distribution of learning materials quickly among students especially.

It can be concluded that the use of WhatsApp as a discussion forum and the dissemination of material, learning can be done one way is to form WhatsApp Group, within WhatsApp the group will be automatically known if one sends a certain message and the other can provide clear responses related to the topic want to be discussed. In the discussion forum and the dissemination of learning materials on WhatsApp media, students are expected to be able to apply or make the most of it, so that learning resources can be created and achieved through social media. WhatsApp mobile application consists of some features, texts which is simple and reliable, group chat which keeps in touch, WhatsApp voice and video calls and WhatsApp on web and desktop. These features can help students to conduct English language learning.

Preliminary observations of the study show that students still feel awkward, ashamed, afraid and tense in English Economics lectures. They tend to be passive in learning activities during lectures both in practical activities, and in discussions, not only because of their weak English skills but also because they lack confidence and fear of being wrong. This causes lectures to become boring and unattractive because learning is centered on lecturers, while on one side English requires a lot of practice to improve four language skills; listening, speaking, writing, and reading.

It is this passive lecturing condition that encourages researchers to try to use WhatsApp media especially WhatsApp Grouping as a medium in English Economics lectures other than in class. The use of WhatsApp was chosen as the media because WhatsApp is the most popular social media message sender today so that it allows all students to know and have WhatsApp. In this study, researchers tried to describe the use of WhatsApp, specifically WhatsApp Grouping in English Economics lectures. Researchers see the use of WhatsApp grouping in lectures can be a solution to the limited time of lecture meetings that are only done 90 minutes a week, and the presence of features in WhatsApp Grouping, English learning is not only centered on lecturers as well as in class, but will be more centered on the activeness of all group members both lecturers and students where and whenever, because it is more relaxed in discussing than in class there is an awkward feeling, and shame experienced by students when interacting and practice speaking English.

Some studies conducted by some researchers about utilizing WhatsApp in English language learning. Alsaleem (2013) examined the effect of the use of WhatsApp on English as Foreign Language (EFL) students in written vocabulary tasks in Saudi Arabia. The author found that WhatsApp had a positive effect on students' performances. The students enjoyed using WhatsApp as a learning tool. They perceived the use of WhatsApp as a game rather than a formal class requirement. Ngaleka and Uys (2013) reported that WhatsApp can be used to facilitate mobile learning. In their study the students used WhatsApp as a communication tool outside the classroom to exchange information about meetings and projects. Barhoumi (2015) found that the use of WhatsApp to facilitate blended learning had a positive and significant impact on students' 
learning performance and their attitudes toward blended learning. Malecela (2016) examined students' perceptions of the use of WhatsApp as a learning tool in university in Malaysia. A qualitative research design was followed in which interviews were conducted with some students. The results showed that the students believed that WhatsApp could be helpful in their learning by facilitating: communication with other students and with the instructor, collaborative learning, and access to and sharing of educational information. WhatsApp can be used as a medium for learning and teaching the English language.

\section{METHOD}

\section{A. Research Design}

The method used in this research is descriptive qualitative case study approach. In other words, the researcher will describe, record, analyze and interpret the conditions that occur or exist in the English Economics group. In this case the phenomenon under study is the use of WhatsApp Group in improving the ability of English Economics students. The object under study in this study is the interaction, communication and utilization of WhatsApp Grouping online media in English Economics lectures in the Faculty of Economics and Business students.

\section{B. Participants.}

The selection of informants in the study used the purposive sampling technique. Therefore, consideration of the selection of informants in the study is based on the following criteria: (1) all students majoring in management and accounting both regular classes and second semester student employees who get English Economics 1 course material; (2) join and become an active member of the WhatsApp Group English Economics 1. Total informants in this study amounted to 177 members of WhatsApp lecture groups from 8 classes.

\section{Instruments}

In this study, the researchers used primary data obtained through the spread of online semi-structured interviews sending to group and all group members are free to answer it and submit directly online through link, in-depth observations of WhatsApp group activities and documentation, documents related to the communication and interaction process on the WhatsApp application in the WhatsApp Group in English Economics 1 lectures, namely recovery materials, audio / sound recordings used for task activities, photos, presentations, interaction and communication contents. Pretest and posttest result. Secondary data used are data obtained from literature studies. Researchers use various types of documents such as journals, handbooks, related documents on the internet that have relevance to this research.

\section{Data Analysis}

In this study technical triangulation was carried out by revealing data about the activity of using WhatsApp application using online interview techniques, then checked by observation to the WhatsApp Group chat room in English Economics 1 where lecturers were able to provide lecture material and communication outside of lecture hours to members of WhatsApp Group lectures English Economics 1.
E-Observation is done by observing the process of interaction and communication of WhatsApp group members in the English Economy class 1. To make observations in the WhatsApp group in English Economics lecture 1, researchers join the WhatsApp group in English Economics lecture 1 and participate in interaction and communication in groups. The interviews used in this study are semi-structured interviews distributed online. Students can fill out interviews by reading the WhatsApp Grouping class and directly clicking the link provided. Click the link directly to the Google Form provided by the researcher. In this study In this online interview the researchers used the Google form with the link bit.ly/ interviewonline1 to find out about interactions and communication in the WhatsApp group and bit.ly/ interviewonline 2 to find out the use of WhatsApp Group in English Economics 1 lectures in improving students' English abilities. Pretest and posttest also conducted for measuring students' achievement before and after use WhatsApp Group for supporting English learning.

\section{FINDINGS AND DISCUSSION}

From the results of informant interviews and researchers observations of the activities in the WhatsApp lecture group, it was seen that group members who were students felt the development of their abilities and the emergence of motivation in learning English, which at first they did not like and were interested in in English because they were considered difficult, confusing, and complicated, do not understand the meaning of words and meanings, but with WhatsApp groups and communication interaction lectures in their groups become motivated to learn English better. This statement is supported by the result of interview section.

"At the first, I did not like English because many words were difficult to understand, but because of frequent communication in WhatsApp group and often hearing and saying English. It turns out that English is fun and it motivates me to be able to communicate English properly and correctly."

"WhatsApp group creates a sense of confidence if we are able / confident to communicate in English ... against fear / shame because they do not face to face when communicating in English. It's different when we communicate directly and it creates a feeling of insecurity for fear that what is said there is a wrong word."

According to the chart below, the finding revealed that students had very good ability for four English skills toward using WhatsApp group. It can be seen from the result of online interviews which is $84 \%$. This number indicates that WhatsApp Group brings benefit for the students. $92 \%$ of students agree that they can easily do interaction with others through WhatsApp message (Chat feature). This chat feature enables them to discuss materials to their friends and lecturers. By having this feature, students can easily send message anytime and anywhere. As it is supported by Cohavi (2013) who said that WhatsApp is learning resources can be accessed anytime, anywhere and in any features. It could help in developing the student's learning performance though. From the data, it can be seen that the usefulness of WhatsApp which equipped with internet connection and supported by some features has improve their English ability as shown in Figure 1. 


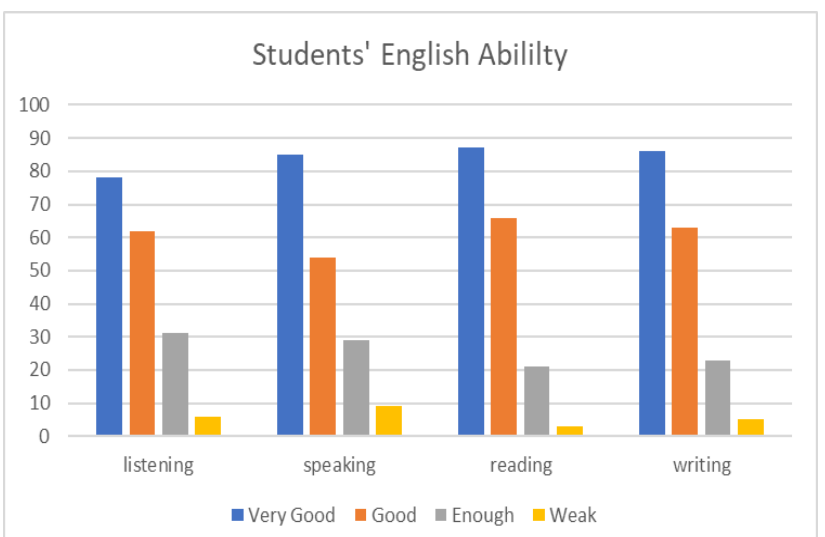

Fig. 1. Students' English Ability

Related to the use of WhatsApp group English Economics 1 lectures in improving the English language skills of students from all answers to online interview questions to all informants and also analysis of the results of observing the activities in the WhatsApp group lecture researchers concluded that the WhatsApp group is useful as a medium media to improve economics students' English language skills in which includes four competencies in reading, listening, writing and speaking. This statement is supported with result of the pretest and posttest. From the pretest and posttest chart below we can see that posttest student's achievement increase if we compare with students pretest result. This achievement as evidence that WhatsApp group can be as tool or media for supporting English learning outside class.

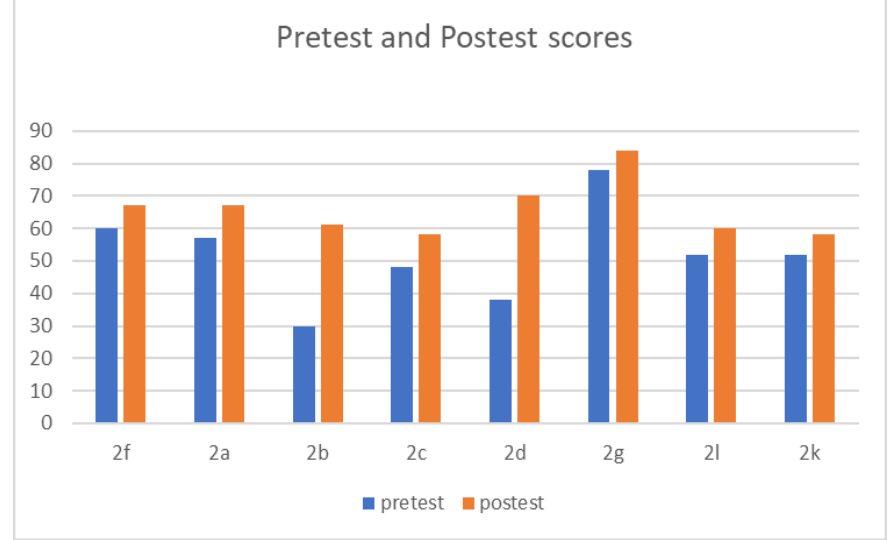

Fig. 2. Pretest and posttest average result

As shown in Figure 2, The result of pretest and posttest also shown that After joining online class in WhatsApp Group, the students showed significant improvement towards four English skills.

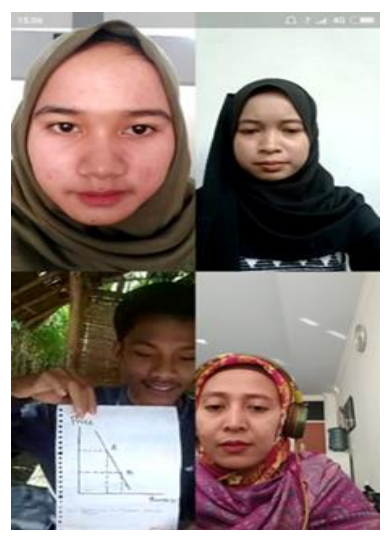

Fig. 3. Speaking practive

Figure 3 depicts one of the activities in the WhatsApp group that contained drilling speaking such as the practice of individual and group English presentations, role play online and offline were felt by students to be able to improve their speaking skills and self-confidence compared to before because the students felt ample opportunities when compared to the classroom lack of practice because of lecture hours and lack of confidence. By doing speaking practices, they built good interaction and communication to WhatsApp Group members. This statement is supported by Narti (2016) who found that Speaking ability can be observed through 2 indications; (1) ability to express ideas, and (2) ability to interact.

Students also take advantage of audio and video uploaded for listening exercises, as shown in Figure 3, so that they feel familiar with the pronunciation of native speakers and can understand the meaning or things conveyed in the audio, The shared audio media grouped by WhatsApp allows students to learn to listen to the material independently so that it is expected to increase effectiveness in the student learning process. This is an indication that WhatsApp group as a medium that can be used to improve student listening. It is also supported by Hamad (2017) that student group members who have downloaded flexibly both in terms of time and place can use the audio listening.

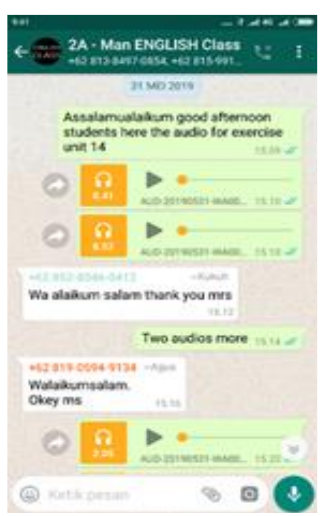

Fig. 4. Listening practice

The use of WhatsApp groups in improving the ability in writing and vocabulary is felt by group members through group 
discussions on a topic related to lecture material. In order to understand the contents of the topic of discussion they open an online dictionary application so that finding new vocabulary meanings is here increasing vocabulary dissertation, which then they make sentences with the new word newly uploaded in discussion activities in the group as shown in Figure 5.

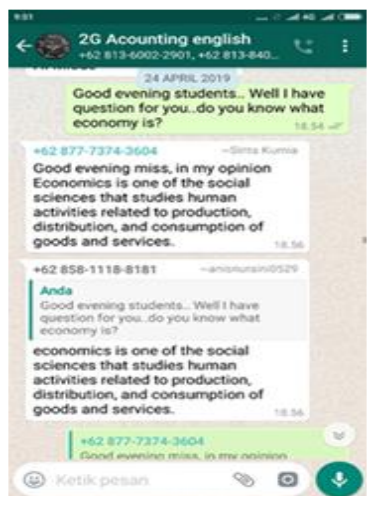

Fig. 5. Writing and reading practices

The process of students using an online dictionary application to translate the meaning of words and even sentences indirectly improve their translation skills. Some students also agree that WhatsApp helps them to learn English easier. This point explains that when discussion is done using English, some students might learn better. They can easily understand the conversation. Unless, they can easily ask for clarification. In addition, students can get more vocabulary. It is because when texts are written in English, students can enrich their vocabulary. They possibly find a new words. Therefore, they can add the new words on their memory. Wahyuni and Febianti (2019) reported that using WhatsApp group discussion could significantly improve students' writing achievement.

Meanwhile, the use of WhatsApp lecture groups in improving reading skills can be seen by researchers that in group interaction activities there are lecture material that is uploaded and can be downloaded by students who facilitate lecturers to read and record and upload the group to be taken for research. This reading practice is felt by students to help them in terms of correct oral reading such as pronunciation and intonation.

\section{CONCLUSION}

Based on the results of research and data collection through online interviews with 177 active student as informants, interaction observation and communication in the WhatsApp group in English Economics lectures and documentation of activities in WhatsApp it can be concluded that the majority of group members who become informants stated that WhatsApp grouping in lectures has benefits in improving ability their
English is seen from their competence in listening, writing, reading and speaking. The statement supported with the result of online interview, documentation, observation and also pretest and posttest result.

WhatsApp grouping is a solution to the limited time of lecture meetings which are only done 90 minutes a week. By utilizing the features in WhatsApp Grouping, English learning is not only centered on lecturers as it is in class, but is more centered on the activeness of all group members both lecturers and students where and when course, because it is more relaxed in discussion than in class with feelings of awkwardness and shame. With WhatsApp grouping media, lecturers are more creative in providing summaries of reading material, grammar, additional training (drilling) for listening through audio sent. The enrichment of speaking with short videos both with presentations and role play is expected to improve students' English skills.

The existence of WhatsApp grouping lectures is used as a medium of communication for sources of information sharing especially around English lectures such as lecture material, lecture assignments where students can easily send back work results, either in the form of direct comments in chat, pictures / captions, recorded dialogues, questions answer material, and share photos.

\section{ACKNOWLEDGMENT}

Thank you to the Directorate of Research and Community Service for funding this research which is a Beginner Lecturer Research funding in 2019.

\section{REFERENCES}

Alsaleem, B. I. A. (2013) "The effect of "WhatsApp" electronic dialogue journaling on improving writing vocabulary word choice and voice of EFL undergraduate saudi students". Arab World English Journal, 4(3), 213-225. doi: 10.31235/osf.io/gux3h

Cohavi, A. (2013). How did WhatsApp became the strongest social network?,2013. Retrieved from http://www/calcalist.co.il/local/articles/0,7340,L-3593840,00.html

Hamad, M. M. (2017) Using WhatsApp to enhance students' learning of English language "Experience to Share." Higher Education Studies, 7(4), 74-87. doi: 10.5539/hes.v7n4p74

Malecela, I. O. (2016). Usage of WhatsApp among postgraduate students of kulliyyah of education, International Islamic University Malaysia. International Journal of Advanced Engineering Research and Science, 3(10), 126-137. doi: 10.22161/ijaers/310.21

Narti, S. (2017) Pemanfaatan "WhatsApp" sebagai media komunikasi dosen dengan mahasiswa bimbingan skripsi. Jurnal PROFESSIONAL, 4(1), 2644 .

Ngaleka, A., \& Uys, W. (2013). M-learning with WhatsApp: A conversation analysis. In E. Ivala (Ed.), $8^{\text {th }}$ International Conference on e-learning (pp. 282-291). Cape Town: Academic Conferences

Wahyuni, S., \& Febianti, K. (2019) The use of WhatsApp group discussion to improve students' writing achievement. Indonesian Educational Administration and Leadership Journal, 1(1), 45-51. 